\title{
Analisis Usahatani Ubi Kayu Varietas Gajah (Studi Kasus di Kelompok Tani-Ternak Kerti Winangun, Desa Bukti, Kecamatan Kubutambahan, Kabupaten Buleleng)
}

\author{
I NENGAH MARDIKA, I KETUT RANTAU, \\ PUTU UDAYANI WIJAYANTI
}

\author{
Program Studi Agribisnis, Program Non Reguler, Fakultas Pertanian, \\ Universitas Udayana. \\ Jl. PB Sudirman Denpasar 80232 \\ Email: rantau1956@yahoo.com \\ mardinegara@yahoo.com
}

\begin{abstract}
Farming cassava analysis of Gajah varieties (Case study in farmer livestock group Kerti Winangun, Bukti Village, Kubutambahan Sub-District, Buleleng Regency)
\end{abstract}

Cassava is one of crops that economically potential to be developed in order to meet food needs in addition to rice. Village of Bukti, Sub-District of Kubutambahan, is one of the cassava production centers in Buleleng, but the locally developed cassava waslower in its production and productivity. In order to improve the productivity and production of cassava, the Farmers Group of Kerti Winangun of Bukti Village have developed superior cassava varieties of Gajah. This study aimed to determine the revenue, $\mathrm{R} / \mathrm{C}$ ratio, and the constraints of farming cassava varieties of Gajah by the Farmers Group of Kerti Winagun at Bukti Village. The choice of location was done purposively and to determine the respondents, it was conducted by census. The results of the research of farm cassava varietiesof Gajah in the planting season of 2015 shows that the production cost of $\mathrm{Rp}$. 15,738,424.00, with the revenue amounting to Rp. 47,367,300.00, which generated revenues of Rp. 31,628,876.00 per hectare with $\mathrm{R} / \mathrm{C}$ ratio of 3.00 means that farming is profitable or feasible to proceed. Technical constraints faced were limited cassava seeds, and the attack of white pest. Economic constraint was the lower price of potatoes soggy in the market. Climate constraint was the low rainfall. Farmers are advised to take advantage of cuttings of cassava of Gajah varieties of the previous harvest, to perform processing of crops so as to increase the sale value, as well as building ponds to collect rain water for watering plants that can be helpful in the dry season.

Keywords: farming, cassava, high yielding varieties of Gajah

\section{Pendahuluan}

\subsection{Latar Belakang}

Indonesia sebagai salah satu negara berkembang yang memiliki luas lahan, agroklimat dan sumberdaya tenaga kerja sub sektor pertanian yang memadai, sangat 
potensial untuk mengembangkan sektor pertanian untuk memenuhi kebutuhan bahan pangan. Kondisi ini menjadi keharusan untuk meningkatkan produksi, penganekaragaman sumberdaya pangan dalam upaya optimal untuk mengimbangi kebutuhan pangan seiring meningkatnya jumlah penduduk. Potensi tersebut belum bisa dimanfaatkan secara optimal.

Ketersediaan lahan kering di beberapa daerah di Provinsi Bali belum diusahakan optimal, yang sesungguhnya dapat dimanfaatkan untuk ekstensifikasi dan diversifikasi pangan. Ubi kayu merupakan salah satu tanaman pangan yang berpotensi ekonomi untuk dikembangkan di lahan kering. Produksi ubi kayu di Provinsi Bali sebesar 86.070 ton, didukung oleh delapan kabupaten, salah satunya Kabupaten Buleleng ( Dinas Pertanian Provinsi Bali, 2015). Produksi ubi kayu di Kabupaten Buleleng sebesar 7.887 ton, pengembangan ubi kayu tersebar di beberapa wilayah kecamatan salah satunya Kecamatan Kubutambahan, tepatnya di Desa Bukti, pada Kelompok Tani-Ternak Kerti Winangun (Dinas Pertanian dan Peternakan Kabupaten Buleleng, 2015).

Upaya peningkatan produksi dan produktivitas ubi kayu, petani di Kelompok Tani-Ternak Kerti Winangun Desa Bukti memilih ubi kayu varietas unggul yaitu ubi kayu varietas Gajah. Ubi kayu ini memiliki sumber gizi yang cukup lengkap, dan memiliki potensi hasil 100 sampai dengan 150 ton per hektar sehinga berpotensi untuk dapat diolah menjadi bahan pangan jadi (kue) atau setengah jadi (tepung kanji dll), sebagai bahan baku energy (bioetanol), berpotensi untuk mengurangi bahkan menggantikan bahan pangan dari beras. Melihat dari keunggulan ubi kayu varietas Gajah diyakini dapat meningkatkan produktivitas dan produksi ubi kayu tepatnya di Desa Bukti, Kecamatan Kubutambahan, Kabupaten Buleleng . (Guntoro 2015) Peningkatan produktivitas dan produksi akan berdampak terhadap pendapatan yang diterima petani, maka dilakukan penelitian analisis usahatani ubi kayu varietas Gajah di Kelompok Tani-Ternak Kerti Winagun, Desa Bukti, Kabupaten Buleleng.

\subsection{Tujuan Penelitian}

Penelitian ini bertujuan untuk mengetahui seberapa besar pendapatan yang diterima petani, kelayakan atau $\mathrm{R} / \mathrm{C}$ ratio , dan kendala- kendala yang dihadapi petani di Kelompok Tani-Ternak Kerti Winangun Desa Bukti, Kecamatan Kubutambahan, Kabupaten Buleleng dalam berusahatani ubi kayu varietas Gajah.

\section{Metode Penelitian}

\subsection{Lokasi dan Waktu Penelitian}

Penelitian ini dilakukan di Kelompok Tani-Ternak Kerti Winangun Desa Bukti, Kecamatan Kubutambahan, Kabupaten Buleleng. Pemilihan lokasi penelitian dilakukan secara purposive sampling, yaitu penentuan lokasi secara sengaja dengan dasar pertimbangan tertentu. Pengumpulan data dilakukan pada bulan Agustus sampai dengan September 2016. 


\subsection{Penentuan Populasi dan Responden}

Populasi merupakan kumpulan individu atau objek penelitian yang memiliki ciri-ciri yang telah ditetapkan. Berdasarkan ciri-ciri tersebut, populasi dapat dipahami sebagai kelompok unit analisis atau objek pengamatan yang minimal memiliki satu persamaan karakteristik. Responden adalah bagian dari populasi yang memiliki karakteristik yang relatif sama dan dianggap bisa mewakili populasi (Hakim, 2004). Ruang lingkup populasi dalam penelitian ini meliputi seluruh petani yang membudidayakan ubi kayu varietas Gajah dan tergabung dalam anggota Kelompok Tani-Ternak Kerti Winangun, Desa Bukti, Kecamatan Kubutambahan, Kabupaten Buleleng berjumlah 32 orang.

\subsection{Metode Pengumpulan Data, Variabel Penelitian, dan Analisis Data}

Teknik pengumpulan data yang digunakan dalam penelitian ini menggunakan tehnik pengamatan (Observation), wawancara dan studi kepustakaan. Variabel merupakan suatu objek yang mempunyai nilai yang bervariasi, yang dipelajari oleh peneliti dan ditarik simpulannya. Variabel juga dapat diartikan sebagai segala sesuatu yang akan menjadi objek pengamatan penelitian yang memiliki nilai yang bervariasi (Antara, 2006). Variabel dalam penelitian ini adalah pendapatan usahatani ubi kayu varietas Gajah, diukur secara kuantitatif dan kualitatif. Analisis data yang digunakan dalam penelitian ini adalah analisis pendapatan, analisis $\mathrm{R} / \mathrm{C}$ ratio, dan analisis deskriptif.

\section{Hasil dan Pembahasan}

\subsection{Karakteristik Responden}

Karakteristik responden yang dijelaskan antara lain ; 1) Umur, merupakan lamanya responden hidup di dunia ini hingga dilakukannya penelitian ini. Kisaran umur keseluruhan responden adalah 15 sampai dengan 60 tahun dengan rata-rata umur 45 tahun. 2) Jika diketahui tingkat pendidikan maka dapat diketahui pula kemampuan seseorang dalam menyerap pengetahuan. Data penelian menunjukan bahwa yang tidak tamat SD sebanyak tujuh orang atau 21,88\%, petani yang tamat SD sebanyak sembilan belas orang atau $59,38 \%$, petani yang tamat SMP sebanyak dua orang atau 6,25\%, petani yang tamat SMA sebanyak empat orang atau $12.50 \%$, dan tidak ada petani yang menamatkan pendidikan pada tingkat perguruan tinggi. 3) Penguasaan lahan, Penguasaan lahan merupakan keseluruhan luas lahan yang sedang digarap baik yang dimiliki sendiri, menyewa maupun menyakap. Luas penguasaan lahan berpengaruh terhadap banyaknya pendapatan yang diterima oleh petani, semakin luas penguasaan lahannya maka semakin tinggi produksi yang bisa dihasilkan dan secara otomatis pendapatannya pun semakin meningkat (Soekartawi, 2006). Total luas lahan garapan dari 32 petani responden seluas 41,80 hektar, yang terdiri 16,43 hektar milik sendiri, 23,85 hektar dari lahan menyakap, 1,52 hektar dari menyewa. Rata-rata luas lahan garapan petani responden seluas 1,31 hektar. 4) Pekerjaan, Pekerjaan dibedakan menjadi dua yaitu, pekerjaan pokok dan pekerjaan 
sampingan. Berdasarkan hasil penelitian dari 32 responden, sebanyak $100 \%$ pekerjaan pokoknya adalah petani. Pekerjaan sampingan petani responden yaitu sebagai buruh tani sebanyak 11 orang atau $34 \%$, sebagai buruh bangunan sebanyak sembilan orang orang atau $28 \%$, sebagai pedagang/bisnis lima orang atau $16 \%$, tukang banten sebanyak satu orang $(0,3 \%)$, dan sisanya sebanyak enam orang $(19 \%)$ tidak memiliki pekerjaan sampingan.

\subsection{Analisis Pendapatan Usahatani}

\subsubsection{Struktur Biaya Usahatani}

Biaya usahatani dalam penelitian usahatani ubi kayu varietas Gajah dikonversikan ke hektar pada satu musim tanam Pengeluaran total usahatani didefinisikan sebagai nilai dari semua masukan yang habis dipakai atau dikeluarkan dalam proses produksi, tetapi tidak termasuk tenaga kerja dalam keluarga (Soekartawi dkk 1986).

\subsubsection{Biaya Tenaga Kerja}

Biaya tenaga kerja dalam penelitian ini berasal dari biaya tenaga kerja dalam keluarga, tanpa mengunakan tenaga kerja luar keluarga. Besarnya biaya tenaga kerja dalam keluarga diukur dengan memakai satuan hari orang kerja (HOK). Biaya Tenaga Kerja per Luas Lahan yang Diusahakan (LLD) 0,05 ha dan per Hektar dalam Usahatani Ubi Kayu Varietas Gajah Musim Tanam di Tahun 2015, Rata-rata biaya tenaga kerja dalam rumah tangga responden usahatani ubi kayu varietas Gajah per hektar sebesar Rp.7.995.259,20. Data selengkapnya disajikan pada Tabel 1.

Tabel 1.

Biaya Tenaga Kerja per Luas Lahan yang Diusahakan (LLD) 0,05 ha dan per hektar dalam Usahatani Ubi Kayu Varietas Gajah Musim Tanam di Tahun 2015.

\begin{tabular}{llcr}
\hline \multirow{2}{*}{ No Jenis Kegiatan } & \multicolumn{2}{c}{ Rata-rata } \\
\cline { 3 - 4 } & & LLD $(0,05)$ ha & \multicolumn{1}{c}{ Per ha } \\
\hline 1 & Pembersihan dan pengolahan lahan & $112.285,16$ & $2.245 .703,20$ \\
2 & Penanaman & $38.144,50$ & $762.890,00$ \\
3 & Pemupukan & $84.997,40$ & $1.699 .948,00$ \\
4 & Penyiangan dan pembubunan & $54.140,60$ & $1.082 .812,00$ \\
5 & Panen & $110.195,30$ & $2.203 .906,00$ \\
\hline \multicolumn{2}{r}{ Total (Rp) } & $399.762,96$ & $7.995 .259,20$ \\
\hline
\end{tabular}

\subsubsection{Total Biaya Produksi}

Total biaya usahatani (total farm expenses) didefinisikan sebagai nilai semua masukan yang habis pakai atau dikeluarkan di dalam proses produksi tetapi tidak termasuk tenaga kerja keluarga petani (Kadariah, 1988). Biaya produksi dalam penelitian ini dibedakan menjadi dua, yaitu biaya tetap (fixed cost) dan biaya tidak 
tetap (variable cost). Biaya tetap per hektar sebesar Rp. 285.289,80, sedangkan Biaya variabel per hektar yang dikeluarkan sebesar Rp. 15.990.518,40, Jadi total biaya produksi per hektar sebesar Rp. 16.275.808,20. Data selengkapnya tersaji pada Tabel 2.

Tabel 2.

Biaya Produksi per Luas Lahan yang Diusahakan Ubi Kayu Varietas Gajah 5 are dan per Hektar Usahatani Ubi Kayu Varietas Gajah dalam Satu Musim Tanam di Kelompok Tani-Ternak Kerti Winangun, Tahun 2015

\begin{tabular}{|c|c|c|c|}
\hline \multirow{2}{*}{ No } & \multirow{2}{*}{ Uraian Biaya } & \multicolumn{2}{|c|}{ Uahatani Ubi Kayu Varietas Gajah } \\
\hline & & $\overline{R p / L L D ~(0,05 h a)}$ & $\mathrm{Rp} / \mathrm{ha}$ \\
\hline \multirow[t]{8}{*}{1} & Biaya Tetap: & & \\
\hline & 1.1 Pajak & $7.500,00$ & $15.000,00$ \\
\hline & 1.2 Alat Pertanian & & \\
\hline & 1.2.1 Penyusutan cangkul & $1.091,66$ & $21.833,20$ \\
\hline & 1.2.2 Penyusutan sabit & $1.200,83$ & $24.016,60$ \\
\hline & 1.2.3 Penyusutan singkal & $3.272,00$ & $65.440,00$ \\
\hline & 1.3 Iuran kelompok & $24.000,00$ & $24.000,00$ \\
\hline & Total Biaya Tetap & $37.064,49$ & $285.289,80$ \\
\hline \multirow[t]{15}{*}{2} & Biaya Variabel: & & \\
\hline & 2.1 Stek ubi kayu & $150.000,00$ & $3.000 .000,00$ \\
\hline & 2.2 Pupuk kandang & $200.093,75$ & $4.001 .875,00$ \\
\hline & Sub total & $350.093,75$ & 7.001.875,00 \\
\hline & 2.3 Tenaga Kerja & & \\
\hline & 2.3.1 Pembersihan dan & & \\
\hline & Mengolah Lahan & $112.285,16$ & $2.245 .703,20$ \\
\hline & 2.3.2 Penanaman & $38.144,50$ & $762.890,00$ \\
\hline & 2.3.3 Pemupukan & $84.997,40$ & $1.699 .948,00$ \\
\hline & 2.3.4 Pembubunan dan & & \\
\hline & Penyiangan & $54.140,60$ & $1.082 .812,00$ \\
\hline & 2.3.4 Panen & $110.195,30$ & 2.203.906,00 \\
\hline & Sub total & $399.762,96$ & $7.995 .259,20$ \\
\hline & Total Biaya Variabel & $749.856,71$ & $14.997 .134,20$ \\
\hline & Total Biaya & $786.921,20$ & $15.738 .424,00$ \\
\hline
\end{tabular}

Per sekali musim tanam (sembilan bulan) tahun 2015

\subsubsection{Produksi Usahtani}

Produksi merupakan suatu kegiatan atau yang mengubah faktor-faktor produksi (input) menjadi suatu produk (output). Fungsi produksi adalah suatu fungsi yang menunjukan hubungan antara hasil produksi fisik (output) dengan faktor produksi (input) (Mubyarto, 1991). Produksi ubi kayu varietas Gajah dijual maupun dibawa pulang untuk dikonsumsi dalam bentuk umbi basah. Rata-rata produksi per 
hektar ubi kayu varietas Gajah dalam satu musim tanam tahun 2015 sejumlah $31.578,20 \mathrm{~kg}$.

\subsubsection{Penerimaan Usahatani}

Penerimaan usahatani adalah penerimaan dari semua bidang usaha meliputi jumlah penambahan inventaris, nilai penjualan hasil, dan yang dikonsumsi keluarga (Hernanto, 1989). Rata-rata produksi per hektar yang dihasilkan responden usahatani ubi kayu varietas Gajah sebesar 31.578,20 kg dikalikan dengan harga umbi basah Rp1.500,00 per kilogram maka diperoleh penerimaan sebesar Rp. 47.367.300,00 per hektar. Data selengkapnya disajikan pada Tabel 3.

Tabel 3.

Rata-Rata Penerimaan per Luas Lahan yang Diusahakan (LLD) are dan per Hektar Usahatani Ubi Kayu Varietas Gajah dalam Musim Tanam di Kelompok Tani-Ternak Kerti Winangun, Tahun 2015

\begin{tabular}{llcr}
\hline \multirow{2}{*}{ No } & \multirow{2}{*}{ Uraian } & \multicolumn{2}{c}{ Usahatani Ubi Kayu Varietas Gajah } \\
\cline { 3 - 4 } & & per LLD $(0,05$ ha $)$ & per ha \\
\hline 1 & Produksi $(\mathrm{Kg})$ & $1.578,91$ & $31.578,20$ \\
2 & Harga umbi basah $(\mathrm{Rp} / \mathrm{Kg})$ & $1.500,00$ & $1.500,00$ \\
\hline & Penerimaan $(\mathrm{Rp})$ & $2.368 .365,00$ & $47.367 .300,00$ \\
\hline
\end{tabular}

\subsubsection{Pendapatan Usahatani}

Menurut Soekartawi (1995), pendapatan bersih atau keuntungan usahatani adalah selisih antara penerimaan usahatani dan pengeluaran total usahatani, termasuk biaya-biaya yang diperhitungkan seperti biaya tenaga kerja dalam keluarga dan penyusutan alat-alat. Rata-rata pendapatan per hektar yang diterima oleh petani responden usahatani ubi kayu varietas Gajah dalam satu musim tanam sebesar Rp. 31.628.876,00 Data selengkapnya dapat dilihat pada Tabel 4.

Tabel 4.

Rata-Rata Pendapatan per Luas Lahan yang Diusahakan (LLD) yaitu per 0,05 are dan per Hektar Usahatani Ubi Kayu Varietas Gajah, Tahun 2015 


\begin{tabular}{ccrr}
\hline \multirow{2}{*}{ No } & \multirow{2}{*}{ Uraian } & \multicolumn{2}{c}{ Usahatani Ubi Kayu Varietas Gajah } \\
\cline { 3 - 4 } & & per LLD $(0,05)$ & \multicolumn{1}{c}{ per ha } \\
\hline 1 & Produksi $(\mathrm{Kg})$ & $1.578,91$ & $31.578,20$ \\
2 & Harga Umbi Basah(Rp/Kg) & $1.500,00$ & $1.500,00$ \\
& Penerimaan $(\mathrm{Rp})$ & $2.368 .365,00$ & $47.367 .300,00$ \\
3 & Total Biaya Tetap (Rp) & $37.064,49$ & $285.289,80$ \\
4 & Total Biaya Variabel (Rp) & $749.856,71$ & $14.997 .134,20$ \\
& Total Biaya (Rp) & $786.921,20$ & $15.738 .424,00$ \\
\hline Pendapatan (Rp) & $1.581 .443,80$ & $31.628 .876,00$ \\
\hline R/C Ratio & 3,00 & 3,00 \\
\hline
\end{tabular}

Musim tanam bulan September s/d Agustus, Tahun 2015

Pendapatan usahatani sangat tergantung pada banyaknya jumlah produksi, harga produk dan biaya produksi. Semakin tinggi harga jual dan jumlah produksi yang dihasilkan maka semakin tinggi pula pendapatan yang diperoleh. Sebaliknya semakin tinggi biaya produksi yang dikeluarkan justru akan mengurangi pendapatan usahatani yang diperoleh. Upaya dalam meningkatkan pendapatan, petani sebaiknya menekan biaya produksi seminimal mungkin dan berusaha meningkatkan hasil produksi setinggi tingginya dalam berusahatani.

\subsection{R/C Ratio Usahatani}

R/C adalah singkatan dari Return Cost Ratio. Analisis R/C Ratio digunakan untuk membandingkan antara penerimaan dan biaya (Soekartawi, 1995). Berdasarkan data pada Tabel 4 terlihat bahwa R/C ratio dengan penerimaan dan total biaya usahatani ubi kayu varietas Gajah per hektar dalam satu musim tanam sebesar 3,00. Berarti setiap Rp 1,00 modal yang diinvestasikan untuk usahatani ubi kayu varietas Gajah akan memberikan penerimaan sebesar Rp 3,00. Berdasarkan hasil perhitungan $\mathrm{R} / \mathrm{C}$ ratio tersebut dapat dijelaskan bahwa usahatani ubi kayu varietas Gajah di Kelompok Tani-Ternak Kerti Winangun, Desa Bukti memberikan keuntungan dan layak untuk dilaksanakan.

\subsection{Kendala dalam Usahatani}

Kendala dan hambatan-hambatan yang dihadapi petani dalam menjalankan usahataninya, meliputi kendala teknis, ekonomi dan lingkungan/iklim. Berdasarkan hasil penelitian, kendala teknis yang dihadapi petani responden dalam proses budidaya ubi kayu varietas Gajah sebagai berikut, sebanyak 32 orang petani mengalami kendala mengenai terbatasnya stek ubi kayu varietas Gajah sehingga luas tanam tidak maksimal. Sebanyak 25 orang petani mengalami kendala dalam mengendalikan serangan hama putih yang menyerang pada saat musim kering sulit dikendalikan. Kendala ekonomi yang dialami petani responden adalah harga produksi yaitu umbi basah masih rendah, sementara kendala lingkungan adalah rendahnya curah hujan, sehingga tidak dapat berproduksi dengan maksimal. 


\section{Simpulan dan Saran}

\subsection{Simpulan}

Berdasarkan rumusan masalah dan hasil analisis maka dapat disimpulkan bahwa :

1. Usahatani ubi kayu varietas Gajah per hektar per satu kali musim tanam tahun 2015 di Kelompok Tani-Ternak Kerti Winangun Desa Bukti, Kabupaten Buleleng, dengan total biaya sebesar Rp. 15.738.424,00, dan penerimaan sebesar Rp. 47.367.300,00, sehingga diperoleh pendapatan sebesar Rp. 31.628.876,00.

2. R/C ratio usahatani ubi kayu varietas Gajah di Kelompok Tani-Ternak KertiWinagun, Desa Bukti, Kecamatan Kubutambahan sebesar 3,00 yang berarti usahatani ubi kayu Varietas Gajah layak untuk dilanjutkan.

3. Kendala-kendala yang dihadapi petani di Kelompok Tani-Ternak Kertiwinagun, Desa Bukti, Kecamatan Kubutambahan, Kabupaten Buleleng adalah petani mengalami kendala teknis mengenai keterbatasan stek atau bibit ubi kayu varietas Gajah terbatas, dan terdapat serangan hama putih pada tanaman pada musim kering. Kendala ekonomi adalah petani mengeluhkan harga umbi ubi kayu dipasaran masih murah. Kendala iklim adalah rendahnya curah hujan saat tanaman pada fase pembentukan atau pembesaran umbi (umur lima bulan) sehingga tidak dapat berproduksi dengan maksimal.

\subsection{Saran}

Berdasarkan hasil penelitian yang diperoleh, maka dapat disarankan sebagai berikut.

1. Keterbatasan stek ubi kayu varietas Gajah dapat dilakukan dengan memanfaatkan batang ubi kayu varietas Gajah hasil panen sebelumnya dengan maksimal, atau mencari informasi ke dinas terkait untuk memperoleh stek sehingga luas tanam dapat ditingkatkan.

2. Upaya meningkatkan harga jual ubi kayu, perlunya pengolahan hasil panen ubi kayu untuk dapat diolah menjadi bahan pangan jadi seperti kue tradisional Bali, maupun setengah jadi seperti gaplek, tepung Mocav (modification casafa) sebagai pengganti kanji, sehingga nilai jual dapat ditingkatkan.

3. Perlunya dibangun embung untuk menampung air pada saat musim hujan sehingga pada saat curah musim kemarau, air tampungan sebelumnya dapat dimanfaatkan untuk membantu menyiram tanaman.

\section{Ucapan Terima Kasih}

Penulis mengucapkan banyak terimakasih kepada semua pihak yang telah membantu dalam pelaksanaan penelitian ini, terutama kepada ketua serta anggota Kelompok Tani-Ternak Kerti Winangun, Desa Bukti, Kecamatan Kubutambahan, Kabupaten Buleleng.

\section{Daftar Pustaka}


Antara, M. 2006. Bahan Ajar Metodelogi Penelitian Agribisnis. Program Magister Agribisnis Program Sarjana Universitas Udayana. Denpasar.

Dinas Pertanian dan Peternakan Kabupaten Buleleng. 2016. Laporan Produksi dan Produktivitas Tanaman Pangan Kabupaten Buleleng. Buleleng.

Dinas Pertanian Provinsi Bali. 2015. Produksi Ubi Kayu Provinsi Bali (ton).

Guntoro, 2015. Laporan Akhit Tahun. Model Pengembangan Inovasi Pertanian Bioindustri pada Lahan Kering, Dataran Rendah Beriklim Kering di Desa Bukti Kecamatan Kubutambahan Kabupaten Buleleng. BPTP BALI.

Hakim, A. 2004. Statistik Deskriptif untuk Ekonomi dan Bisnis. Jakarta: Ekonesia. Hernanto, F. 1989. Ilmu Usahatani. Cetakan Pertama. Jakarta: PT Penebar Swadaya.

Kadariah, 1988. Evaluasi Proyek Ekonomis. Edisi Dua. Lembaga Penerbit Fakultas Ekonomi Universitas Indonesia. Jakarta.

Mubyarto. 1991. Pengantar Ekonomi Pertanian. Penerbit LP3S Jakarta.

Soekartawi, A. Soeharjo, Jhon L. Dillon, J. Brian Hardaker. 1986. Ilmu Usahatani dan Penelitian untuk Pengembangan Petani Kecil. UI-Press, Jakarta.

Soekartawi. 1995. Analisis Usahatani. Penerbit. Universitas Indonesia. Jakarta. 